\title{
Vertexicola caudatus gen. et sp. nov., and a new species of Rivulicola from submerged wood in freshwater habitats
}

\author{
V. Mala Ranghoo \\ Kevin D. Hyde ${ }^{1}$ \\ Sze-Wing Wong \\ Clement K. M. Tsui \\ Centre for Research in Fungal Diversity, Department of \\ Ecology and Biodiversity, The University of Hong \\ Kong, Pokfulam Road, Hong Kong \\ E. B. Gareth Jones \\ BIOTEC, National Centre for Genetical Engineering \\ and Biotechnology, 73/1 Rama 6 Road, Bangkok \\ 10400, Thailand
}

\begin{abstract}
Vertexicola caudatus gen. et sp. nov., is described and illustrated from submerged wood collected from a creek in the Philippines and a river in Hong Kong. Vertexicola differs from other genera in the Annulatascaceae (Sordariales) in having thickwalled distoseptate ascospores and asci with a tail-like structure. The placement of Vertexicola within the Annulatascaceae is discussed and it is compared with other genera in this family. Rivulicola aquatica sp. nov. is also described and illustrated.
\end{abstract}

Key Words: Annulatascaceae, ascomycetes, lignicolous fungi, systematics

\section{INTRODUCTION}

Several novel and interesting ascomycetes and hyphomycetes have been described from submerged wood in freshwater environments both in tropical and subtropical countries (Chang et al 1998, Hyde and Goh 1997, Hyde et al 1998, Ranghoo and Hyde 1998). During examination of freshwater fungi occurring on submerged wood in Natigbasan Creek, Mindanao, Philippines, and the Plover Cove Reservoir, The New Territories, Hong Kong, we identified several interesting ascomycetes (Goh and Hyde 1999). In this paper we describe Vertexicola caudatus gen. et sp. nov., in the Annulatascaceae that is unique from other genera as it has distoseptate ascospores and asci with tail-like pedicels. We also report on a new collection of Rivulicola incrustata K. D. Hyde in Hong Kong and a new species $R$. aquatica is introduced.

Accepted for publication May 1, 2000.

${ }^{1}$ Corresponding author; email: kdhyde@hkucc.hku.hk

\author{
MATERIALS AND METHODS
}

Submerged wood (decaying, decorticated woody debris of unidentified angiosperms) was collected from the Plover Cove Reservoir and Natigbasan Creek and returned to the laboratory in sterile plastic bags. Samples were incubated in plastic boxes lined with moistened paper towel under ambient laboratory conditions (22-25 C, fluctuating daylight and fluorescent light conditions) and examined periodically over 2-3 mo. Squash mounts of ascomata in water were made for microscopic examination. Measurements of ascomata were made from thin sections or whole mounts in water. The contents of the ascomata were removed from the ascomata and a spore suspension was made with sterile distilled water in a watch-glass and the suspension was pipetted onto potato dextrose agar (PDA). The single ascospores were allowed to germinate (ca $2 \mathrm{~d}$ ) and then they were transferred to smaller PDA plates for further growth.

For scanning electron microscopy (SEM) and transmission electron microscopy (TEM), an ascospore suspension was prepared in distilled water using the ascomatal contents. It was fixed and prepared following the methods described by Ho et al (1999).

\section{TAXONOMY}

Vertexicola K. D. Hyde, V. M. Ranghoo et S. W. Wong, gen. nov.

Ascomata globosa vel sub-globosa, superficialia, immersa vel semi-immersa, membranacea vel coriacea, hyalina, brunnea vel nigra, solitaria vel aggregata, rostratum, periphysatum. Peridium superficie ex textura angulari, ex cellulis pseudoparenchymatis. Paraphyses simplices vel raro ramosae, hyalinae. Asci octospori, unitunicati, cylindrici, pedicellati, apice distincto poro iodo tinto haud coerulescente. Ascosporae fusiformes vel ellipsoideae, hyalinae, crassotunica, 0-6 distoseptatae, uniseriatae vel biseriatae.

Ascomata globose to subglobose, superficial, immersed or semi-immersed, membranous or coriaceous, hyaline, brown or black, solitary or aggregated, beaked. Necks long, lateral, curved upward, black and periphysate. Peridium two layered; outer layer textura angularis, inner layer consists of pseudoparenchymatous cells. Paraphyses wide, tapering and septate. Asci 8-spored, unitunicate, cylindrical, with elongate and tail-like pedicels, and a large, refractive and bipartite (at TEM level) apical ring. Ascospores fusiform or ellipsoidal, hyaline, thick-walled, 0-6-distoseptate, uniseriate or overlapping uniseriate.

Etymology. From the Latin vertex meaning eddy and cola meaning loving. 
Type species. Vertexicola caudatus K.D. Hyde, S.W. Wong \& V. M. Ranghoo sp. nov.

Vertexicola caudatus K.D. Hyde, S.W. Wong et V. M. Ranghoo, sp. nov.

FIGS. 1-18

Ascomata 240-360 $\mu \mathrm{m}$ diam, globosa vel sub-globosa, superficialia vel semi-immersa, coriacea, nigra, solitaria. Rostrum 80-120 $\mu \mathrm{m}$ longum, 40-60 $\mu \mathrm{m}$ diam. Asci 170-290 $\times$ 7.5-12 $\mu \mathrm{m}$, octospori, cylindrici, pedicellati, unitunicati, apice distincto poro iodo tincto haud coerulescente. Ascosporae 18-24 $\times 6-9 \mu \mathrm{m}$, uniseriatae vel biseriatae, ellipsoidaefusiformes, hyalinae, 5-septatae, non-constrictae, cum muris laevigatis.

Ascomata 240-360 $\mu \mathrm{m}$ diam, globose to subglobose, superficial or semi-immersed, coriaceous, black and solitary (FIG. 1). Necks 80-120 $\mu \mathrm{m}$ long, 40-60 $\mu \mathrm{m}$ diam, black, curving upwards and periphysate. Paraphyses $6 \mu \mathrm{m}$ wide, hyaline and septate (FIG. 5). Asci 170-290 × 7.5-12 $\mu \mathrm{m}$, 8-spored, cylindrical, pedicellate, unitunicate, apically rounded, with a large $\mathrm{J}$-, refractive and bipartite apical ring, $4 \mu \mathrm{m}$ long $\times 5 \mu \mathrm{m}$ diam (FIGS. 2, 3, 4). Base of the ascus flask-shaped, with an elongate tail-like pedicel (FIG. $6)$, comprising the inner ascus wall layer which encloses the epiplasm (TEM). Ascospores 18-24 × 6-9 $\mu \mathrm{m}$, uniseriate or overlapping uniseriate, fusiform or ellipsoidal, hyaline, 5-distoseptate, and thick-walled (FIGS. 7-9). Colonies on potato dextrose agar slowgrowing, reaching $1 \mathrm{~cm}$ diam after $30 \mathrm{~d}$ at room temperature $(25 \mathrm{C})$, comprising cottony mycelium, superficial hyphae dark grey, growing in concentric rings, black on reverse. No anamorph or telemorph produced in culture.

Etymology. From the Latin, caudatus = tailed, in reference to the asci with its tail-like pedicel.

Specimens examined. PHILIPPINES. BUKIDNON: Natigbasan Creek Impalutao, Mindanao, on submerged wood, Jan 1994, K.D. Hyde, [HOLOTYPE: HKU(M) 3108], [HKU(M) 3122]. CHINA. HONG KONG: Tai Po, Lam Tsuen River, on submerged wood, Sep 1997, K.M. Tsui, [HKU(M) 8111]. Sai Kung, Hang Cho Shui stream, on submerged wood, Sep 1998, K.M. Tsui, [HKU(M) 12237].

Habitat. Saprobic on wood submerged in freshwater.

Known distribution. Hong Kong, Philippines.

Ultrastructure. Immature ascospores of V. caudatus are nonseptate and ellipsoidal with numerous small lipid guttules (FIG. 10). The wall comprises a thin, electron-dense and discontinuous episporium (ca 10 $\mathrm{nm})$; and a thick, electron-transparent mesosporium (ca $275 \mathrm{~nm}$ ) (Fig. 11). Young ascospores are 1 septate, with larger lipid globules and a thick wall (FIG. 12). In the ascus, each young ascospore is covered by an electron-transparent layer, which is covered by a single-layered delimiting membrane (FIG. 12). Some electron-transparent vacuoles appear to be associated with the electron-transparent layer (FIGS. 12-14). The wall of a mature ascospore comprises an electron-dense episporium (ca $25 \mathrm{~nm}$ ) and a bipartite mesosporium with a thick outer layer, M1 (385-480 $\mathrm{nm}$ ), and a thin inner layer, M2 (ca $19 \mathrm{~nm}$ at the lateral wall and ca $180 \mathrm{~nm}$ at the septum) (FIG. 13). The former mesosporial sublayer (M1) is less electron dense with abundant electron dense fibrillar assemblages (FIGs. 13, 14). The inner wall layer (M2) is more electron dense, occurs adjacent to the plasma membrane, and gives rise to the septum (FIG. 13).

The mature ascus wall of $V$. caudatus is bipartite (FIGS. 13, 15, 16) comprising: (i) an outer electrondense bilamellate layer that is composed of an inner compact thin layer and an outer fibrous layer with fibrils orientated perpendicular to the inner layer (ca $150 \mathrm{~nm}$ ), and (ii) an inner thick electron-transparent layer (0.3-1.4 $\mu \mathrm{m}$ thick). Numerous electron-dense inclusions occur in this layer at the immature stage (FIG. 15), but are absent in mature asci (FIG. 16). The thickness of the inner ascus wall layer increases towards the apical ring and appears to fuse with the apical ring (FIG. 16).

The base of the immature ascus tapers in the region where it breaks from the outer ascus wall (Fig. 17). As a result, a tail-like extension of the inner ascus wall is formed. The base of the mature ascus expands and swells to form a structure which contains copious epiplasm with glycogen rosettes and enclosed by the inner ascus wall (FIG. 18).

The apical ring of the ascus is bipartite (FIGS. 15, 16) comprising an upper part, which is less electrondense and appears to be differentiated from the outer ascus wall, and a lower electron-dense part. $\mathrm{Nu}$ merous electron-dense granular deposits are present at the interface between the upper and lower part of the apical ring (Figs. 15, 16). The lower part of the apical ring elongates downwards during maturation (FIGS. 15, 16) and eventually forms a large ring. The channel of the apical ring has a plug which is of similar electron density to the inner ascus wall (FIGs. 15, 16). A cleft is observed at the centrum of the plug in the mature apical ring (FIG. 16).

Notes. The characteristic features of Vertexicola are asci with refractive apical rings and tail-like pedicels and distoseptate ascospores with relatively thick walls with no appendages or sheaths.

Vertexicola is best placed within the Annulatascaceae because it shares many features similar to other taxa within this family. It has immersed or semi-immersed, membranous to coriaceous, hyaline to black ascomata; wide and septate paraphyses; and cylindrical asci with a wide and refractive apical ring (Hyde and Ho 2000). At the TEM level, the type genus of 

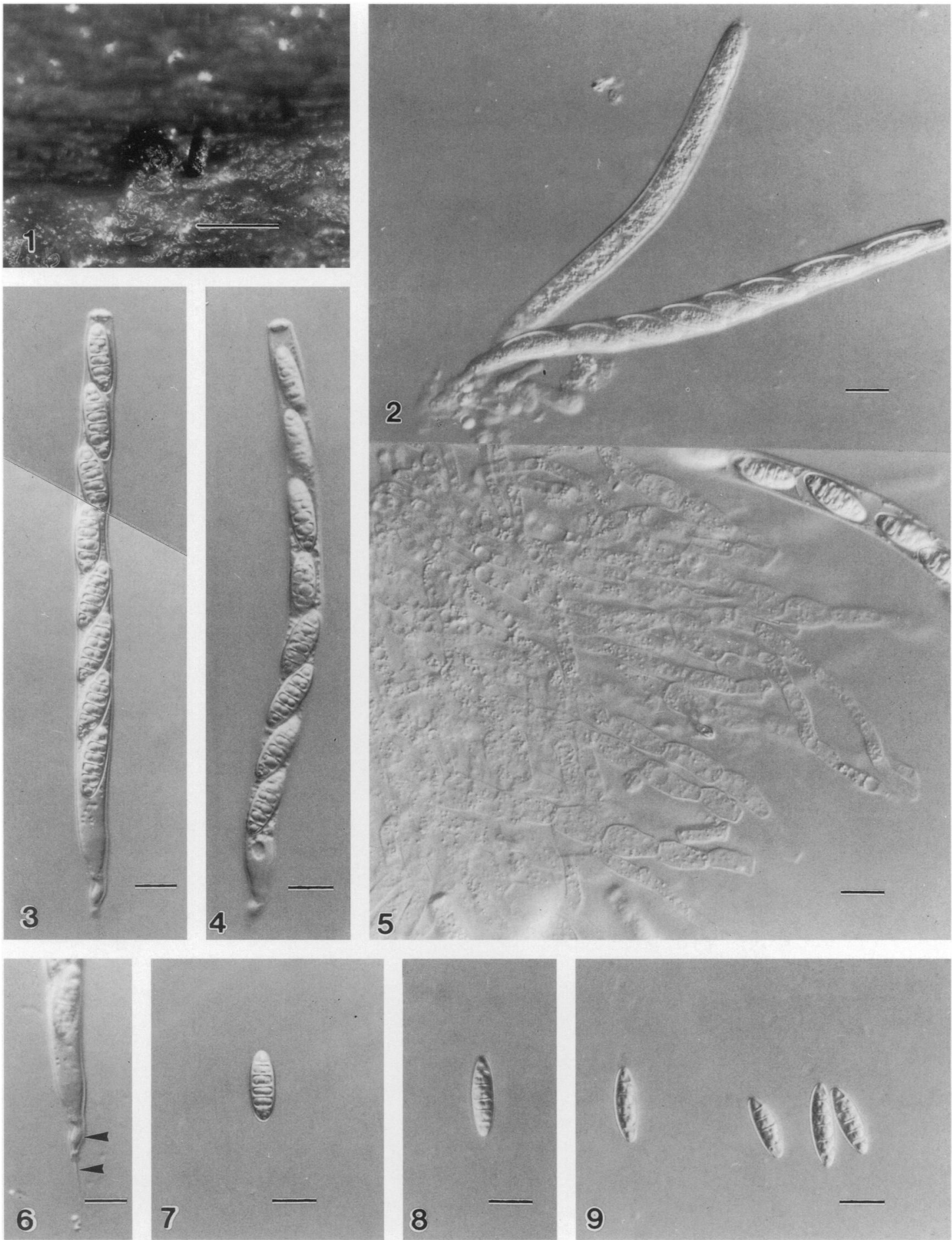

FIGS. 1-9. Vertexicola caudatus (from HOLOTYPE). Interference light contrast micrographs. 1. Semi-immersed ascoma. 2. Immature ascus. 3, 4. Asci with large refractive apical rings. The ascospores are uniseriate or overlapping uniseriate in the asci. 5. Wide septate paraphyses. 6. Ascus base with an elongated tail-like pedicel (arrowed). 7-9. Distoseptate ascospores with thick-walls. Bars: $1=100 \mu \mathrm{m}, 2-9=10 \mu \mathrm{m}$.

the Annulatascaceae, Annulatascus K. D. Hyde, possesses a bipartite apical ring with an upper part derived from the ascus wall and the lower part elongates downward during maturation (Wong et al 1998). Ver- texicola possesses a similar substructure and apical ring ontogeny as in Annulatascus (Wong et al 1998). Unlike other genera within the Annulatascaceae, Vertexicola has distoseptate ascospores without append- 

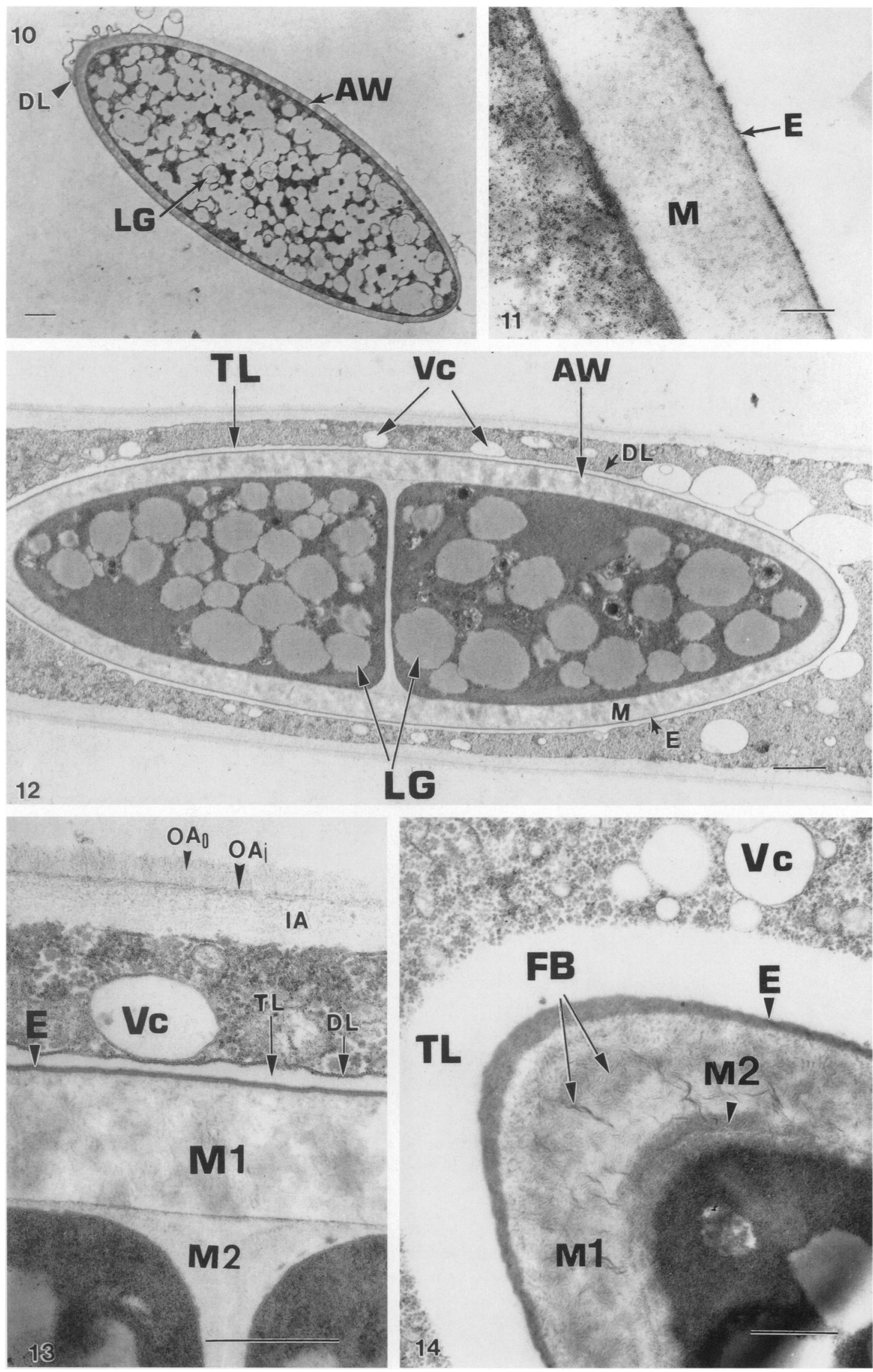
TABLE I. Synopsis of the main characteristics of Rivulicola species

\begin{tabular}{lccc}
\hline \hline & $\begin{array}{c}\text { Rivulicola incrustata } \\
(\text { Hyde et al 1997) }\end{array}$ & $\begin{array}{c}\text { Rivulicola incrustata } \\
{[\mathrm{HKU}(\mathrm{M}) 5224]}\end{array}$ & Rivulicola aquatica \\
\hline Ascomata & $\begin{array}{c}160 \times 280 \mu \mathrm{m}, \text { hyline, neck ap- } \\
\text { pearing green on the wood } \\
\end{array}$ & $\begin{array}{c}210-225 \times 470-510 \mu \mathrm{m}, \text { hyaline } \\
\text { with setae }\end{array}$ & $140-150 \times 175-180 \mu \mathrm{m}, \mathrm{hyaline}$ \\
Asci & $130-205 \times 11-12 \mu \mathrm{m}$ & $120-150 \times 12.5-15 \mu \mathrm{m}$ & $125-162 \times 22-25 \mu \mathrm{m}$ \\
Ascospores & $\begin{array}{l}18-24 \times 6-9 \mu \mathrm{m},(3)-4-(5) \text {-sep- } \\
\text { tate }\end{array}$ & $25-30 \times 6-10 \mu \mathrm{m}, 5-6-\mathrm{septate}$ & $\begin{array}{c}15-20 \times 7.5-12.5 \mu \mathrm{m}, 1-3-\mathrm{sep}- \\
\text { tate }\end{array}$ \\
\hline
\end{tabular}

ages or mucilaginous sheaths; however, the apical ring ultrastructure and ascospore ontogeny can be considered to be the more phylogenetically important characters delineating this family (Hyde and Ho 2000). An anology can be made here with the Halosphaeriaceae, the largest family of marine ascomycetes. Some genera within the Halosphaeriaceae were also described to have ascospores lacking appendages even at the ultrastructural level e.g., Aniptodera Shearer \& M. A. Mill. (Farrant 1986, Shearer and Miller 1977, Shearer 1989), Lignincola Höhnk (Yusoff 1991), Lindra Wilson (Yusoff et al 1995), Nais Kohlm. (Baker 1991).

Within the Annulatascaceae, Vertexicola resembles Proboscispora aquatica S. W. Wong \& K. D. Hyde which produces hyaline 1-3 septate ascospores in cylindrical asci with large refractive apical rings. But when the ascospores of Proboscispora aquatica are in water, polar appendages are released from the ascospore tips.

Molecular studies carried out on several freshwater ascomycetes have provided further evidence for the generic placement of Vertexicola within the Annulatascaceae (Ranghoo et al 1999).

Rivulicola aquatica V. M. Ranghoo et K. D. Hyde, sp.
Ascomata 140-150 $\mu \mathrm{m}$ diametro, 175-180 $\mu \mathrm{m}$ longa, subglobosa, subtrato partim immersa, membranacea, solitaria ad aggregata, rostrum 50-60 $\mu \mathrm{m}$ latum et $50-88 \mu \mathrm{m}$ longum. Paries perithecii 20-30 $\mu \mathrm{m}$ lati. Paraphyses usque $7 \mu \mathrm{m}$ crassae. Asci 125-162 x 22-25 $\mu \mathrm{m}$, octospori, cylindrici, pedicellati, unitunicati, apice annulo $2.5-4 \mu \mathrm{m}$ alto et $4-5 \mu \mathrm{m}$ lato apice distincto poro iodo tincto haud coerulescente. Ascosporae 15-20 × 7.5-12.5 $\mu \mathrm{m}$, overlapping uniseriatae vel biseriatae, ellipsoidae, 1-3-septatae, hyalinae.

Ascomata 140-150 $\mu \mathrm{m}$ diam, 175-180 $\mu \mathrm{m}$ high, subglobose, partly-immersed, membranous, hyaline, solitary to gregarious (FIG. 19). Necks 50-60 $\mu \mathrm{m}$ diam, 50-88 $\mu \mathrm{m}$ high, hyaline to brown, with periphyses. Peridium 20-30 $\mu \mathrm{m}$ wide, comprising 5-7 layers of hyaline, thin-walled compressed cells (FIG. 20). Paraphyses 120-150 $\times 5.6-7 \mu \mathrm{m}$, hyaline, septate rounded and branched (FIG. 23). Asci 125-162 $\times 22-$ $25 \mu \mathrm{m}, 8$-spored, cylindrical, pedicellate, unitunicate, apically truncate, with a refractive, $\mathrm{J}$-, apical ring, and 2.5-4 $\mu \mathrm{m}$ high, 4-5 $\mu \mathrm{m}$ diam (FIGS. 21, 22). Ascospores 15-20 × 7.5-12.5 $\mu \mathrm{m}$, overlapping uniseriate or biseriate, ellipsoidal, 1-3 septate, not constricted at the septa, smooth-walled, hyaline, with thin fibrillar ornamentation on the ascospores (FIGS. 24-26).

Etymology. From the Latin, aquatica = aquatic, in reference to the freshwater habitat where the fungus was found.

Specimen examined. CHINA. HONG KONG: Tai Po, Plover

$\leftarrow$

FIGS. 10-14. Vertexicola caudatus. Transmission electron micrographs. 10. Longitudinal section illustrating an immature ascospore which is thin-walled (arrowed AW) and contains numerous lipid guttules (arrowed LG). Note the remnants of the delimiting membrane (arrowed DL). 11. Higher magnification illustrating the wall of an immature ascospore which comprises a thin electron-dense episporium (arrowed E) and a thicker electron-transparent mesosporium (M). 12. Longitudinal section of young ascospore in an ascus. Ascospores 1 septate, has large lipid globules (arrowed LG), and is surrounded by a thin electron-transparent layer (TL) which is associated with many electron-transparent vacuoles (arrowed Vc). 13. Longitudinal section of mature ascospore within an ascus. Ascospore wall comprises a thin electron-dense episporium (arrowed E), and the mesosporium with an outer thick electron-transparent (M1) and an inner thin more electron-dense layer (M2). An electron-transparent layer (arrowed TL), bounded by a delimiting membrane (arrowed DL), lie outside the ascospore wall. Vacuoles (Vc) are associated with the electron-transparent layer (TL). The ascus wall comprises an outer electron-dense bipartite layer (OA) which is composed of an inner compact thin layer (arrowed OAi) and an outer fibrous layer (arrowed OAo) with fibrils orientated perpendicular to the inner layer and an inner thick electron-transparent layer (IA). 14. Oblique longitudinal section of ascospore tip with electron-dense fibrillar assemblages (arrowed FB) within the inner mesosporium (M1). Note the vacuoles (Vc) associated with the electron-transparent layer (TL). Bars: $10,12=1 \mu \mathrm{m} ; 11=0.1 \mu \mathrm{m} ; 13,14$ $=0.5 \mu \mathrm{m} . \mathrm{E}=$ episporium, M2 = Inner mesosporial layer. 


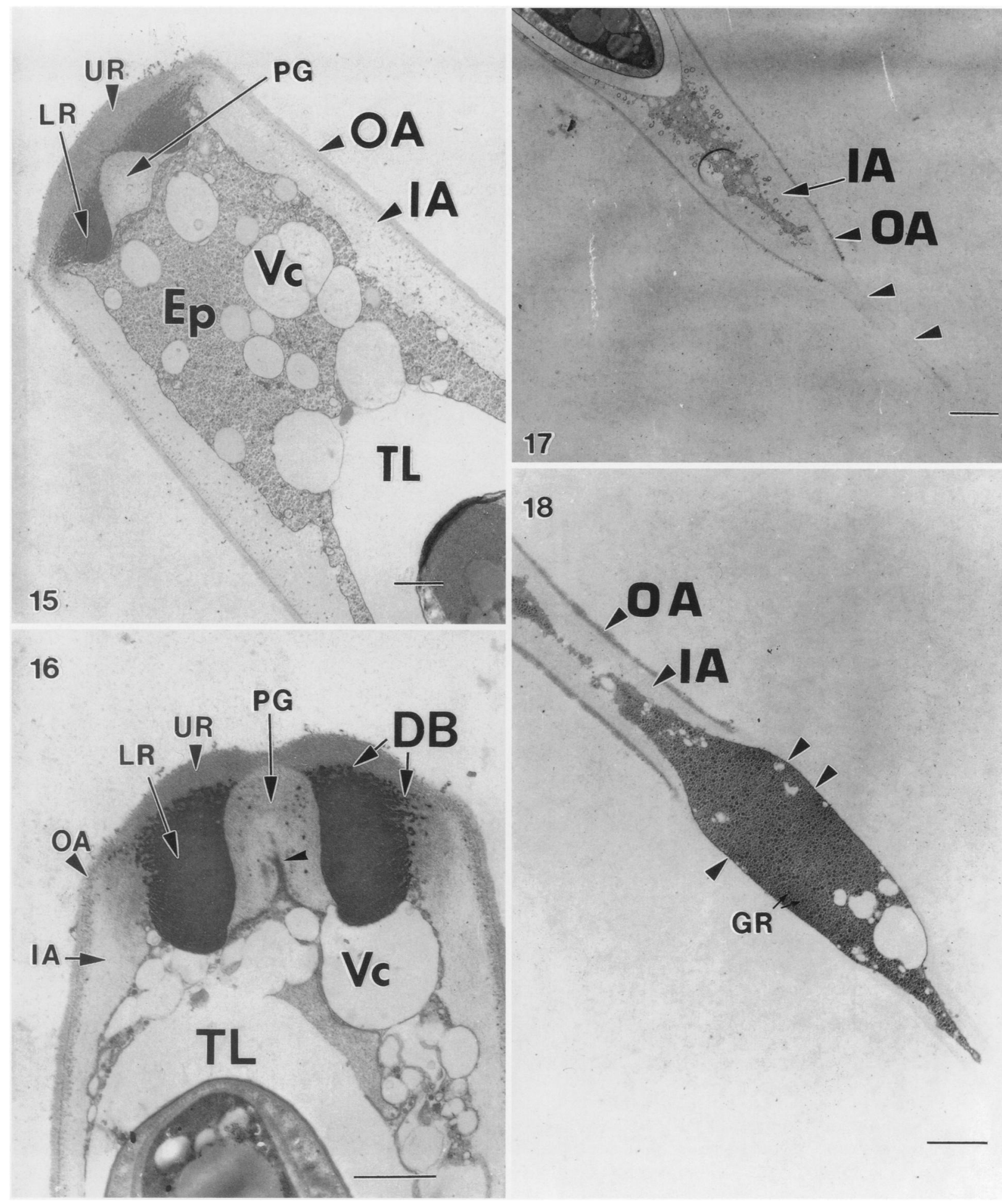

FIGS. 15-18. Vertexicola caudatus. Transmission electron micrographs. 15. Longitudinal section of immature ascus illustrating the apical ring comprising an upper less electron-dense part (arrowed UR) and a lower more electron-dense part (arrowed LR). The upper part appears to be an extension of the outer ascus wall (arrowed OA). An electron-transparent plug (arrowed PG) is present. Note the epiplasm (Ep) which contains many vacuoles (Vc). 16. Longitudinal section of a mature ascus illustrating the upper (arrowed UR) and lower (arrowed LR) part of the apical ring. Electron-dense granular deposits (arrowed DB) are present at the interface between the upper and lower part of apical ring and some occur in the inner ascus wall (arrowed IA) near the apical ring. PG = plug, central cleft arrowed; OA = outer ascus wall 17. Longitudinal section of immature ascus illustrating the tapering base formed by the rupture of the outer ascus wall (OA) with the inner ascus wall (arrowed IA). 18. Longitudinal section of mature ascus illustrating where the base expands and swells (arrowed). Numerous glycogen rosettes (GR) are present in this region. Bars: $15,16,18=1 \mu \mathrm{m} ; 17=5 \mu \mathrm{m}$. 

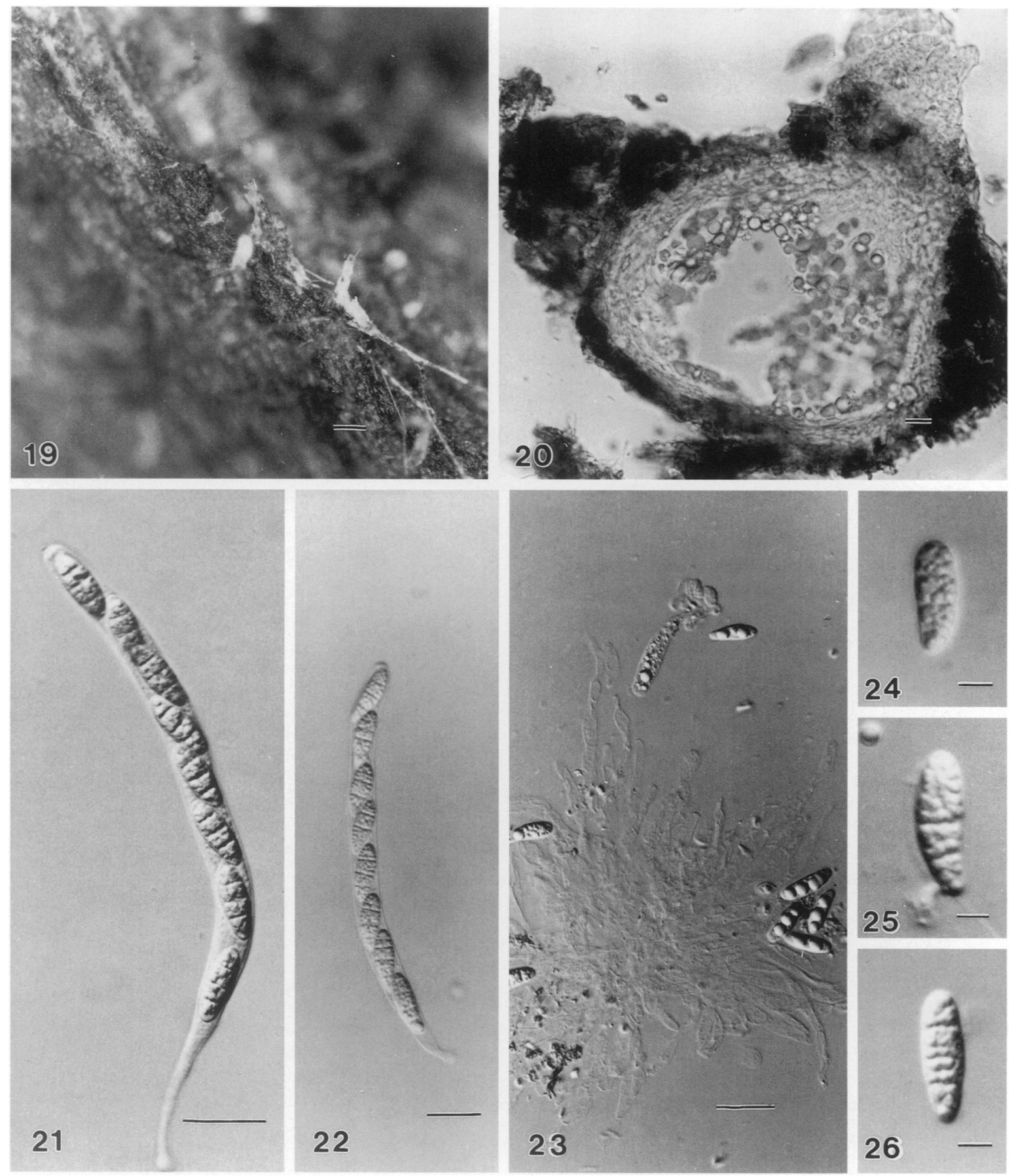

FIGs. 19-26. Rivulicola aquatica. Interference light micrographs. 19. Immersed ascoma with hyaline neck. 20. Section through the ascoma. 21, 22. Mature asci cylindrical. 23. Paraphyses hyaline, wide. 24-26. Ascospores hyaline, 2-3 septate. Bars: $19=100 \mu \mathrm{m}, 20=20 \mu \mathrm{m}, 21=10 \mu \mathrm{m}, 22-23=20 \mu \mathrm{m}, 24-26=5 \mu \mathrm{m}$.

Cove Reservoir, on submerged wood, Jan 1997, V. M. Ranghoo, PC 61 [HOLOTYPE: HKU(M)5214].

Habitat. Saprobic on wood submerged in freshwater.

Known distribution. Hong Kong.

Notes. Rivulicola was introduced for a freshwater ascomycete with hyaline ascomata, cylindrical asci with a discoid refractive apical ring, hyaline, multi- septate, and ellipsoidal ascospores (Hyde et al 1997). There have been some new observations in the recent collection of Rivulicola incrustata from Hong Kong [HKU(M)5224]. The necks of the ascomata are thicker, dome-shaped and covered with hyaline setae and the ascomata do not stain the wood green. The ascospores are 5-6 septate and not surrounded by a mucilaginous sheath unlike those of the original col- 
lection of $R$. incrustata where they are 3-4-5 septate and surrounded by an irregular granular sheath (TABLE I). These differences between the two collections of $R$. incrustata do not warrant the description of a new species.

Rivulicola aquatica has hyaline ascomata, cylindrical asci with a discoid refractive apical ring, hyaline, multiseptate, and ellipsoidal ascospores, all features characteristic of Rivulicola. Rivulicola aquatica, however, differs from $R$. incrustata in having 1-3-septate ascospores. The ascomata have hyaline necks which are devoid of setae and they do not stain the wood green. The differences between Rivulicola species are summarized in TABLE $\mathbf{I}$.

\section{ACKNOWLEDGMENTS}

We are thankful to the Hong Kong Research Grants Council and The University of Hong Kong for grants to study freshwater fungi. V. M. Ranghoo is grateful to The University of Hong Kong for the award of a postgraduate studentship. The technicians at the Queen Mary Hospital, Y. C. Mok, W. S. Lee and S. L. Amy are thanked for their help with the SEM. A.Y. P. Lee and H. Y. M. Leung are thanked for photographic and technical assistance.

\section{LITERATURE CITED}

Baker TA. 1991. Taxonomic studies of the Halosphaeriaceae with special reference to ultrastructure of spore ontogeny [PhD Thesis]. Portsmouth, UK: Portsmouth University. $287 \mathrm{p}$.

Chang HS, Hsieh S-Y, Jones EBG, Read SJ, Moss ST. 1998. New freshwater species of Ascotaiwania and Savoryella from Taiwan. Mycol Res 102:709-718.

Farrant CA. 1986. An electron microscope study of ascus and ascospore structure in Aniptodera and Halosarpheia, Halosphaeriaceae. In: Moss ST, ed. The biology of marine fungi. Cambridge, UK: Cambridge University Press. p 231-243.
Goh TK, Hyde KD. 1999. Fungi on submerged wood and bamboo in the Plover Cove Reservoir, Hong Kong. Fung Divers 3:57-85.

Ho WWH, Hyde KD, Hodgkiss IJ. 1999. Ultrastructure of Annulatascus aquaticus sp. nov., a freshwater ascomycete on submerged wood from Hong Kong. Fung Divers 2:119-128.

Hyde KD, Goh TK. 1997. Fungi on submerged wood in a small stream on Mt Lewis, North Queensland, Australia. Muelleria 10:145-157.

- Ho WH. 2000. A new family of freshwater ascomycetes. Fung Divers 4:21-36.

—, Goh TK, Steinke TD. 1998. Fungi on submerged wood in the Palmiet River, Durban, South Africa. S Afr J Bot 64:151-162.

— tralian freshwater fungi. XII. Rivulicola incrustata gen. et sp. nov. and notes on Ceratosphaeria lampadophora. Nova Hedwigia 64:185-196.

Ranghoo VM, Hyde KD. 1998. Ascolacicola aquatica gen. et sp. nov., and a new species of Ascotaiwania from wood submerged in a reservoir in Hong Kong. Mycologia 90: 1055-1062.

- - L Liew ECY, Spatafora JW. 1999. Family placement of Ascotaiwania and Ascolacicola based on DNA sequences from the large subunit rRNA gene. Fung Divers 2:159-168.

Shearer CA. 1989. Aniptodera (Halosphaeriaceae) from wood in freshwater habitats. Mycologia 81:139-146.

—, Miller M. 1977. Fungi of the Chesapeake Bay and its tributaries. V. Aniptodera chesapeakensis gen. et sp. nov. Mycologia 69:1218-1223.

Wong SW, Hyde KD, Jones EBG. 1998. Annulatascaceae, a new ascomycete family from the tropics. Syst Ascomyce $16: 17-25$.

Yusoff M. 1991. Ultrastructural studies of ascospore appendage ontogeny in selected genera of the Halosphaeriaceae and Pleosporaceae (Ascomycotina) [PhD Thesis]. Portsmouth, UK: Portsmouth University. 227 p.

— Jones EBG, Moss ST. 1995. Ascospore ultrastructure in the marine genera Lulworthia Sutherland and Lindra Wilson. Cryptog Bot 5:307-315. 